\title{
Morphological study of the eggs and nymphs of Triatoma dimidiata (Latreille, 1811) observed by light and scanning electron microscopy (Hemiptera: Reduviidae: Triatominae)
}

\author{
F Mello $^{1 /+}$, J Jurberg ${ }^{2}$, J Grazia $^{3}$ \\ ${ }^{1}$ Instituto de Pesquisas Biológicas, Laboratório Central de Saúde Pública do Rio Grande do Sul, Fundação Estadual de Produção e \\ Pesquisa em Saúde, Porto Alegre, RS, Brasil ²Laboratório Nacional e Internacional de Referência em Taxonomia de Triatomíneos, \\ Instituto Oswaldo Cruz-Fiocruz, Rio de Janeiro, RJ, Brasil ${ }^{3}$ Universidade Federal do Rio Grande do Sul, Porto Alegre, RS, Brasil
}

Eggs and nymphs of Triatoma dimidiata were described using both light and scanning electron microscopy. The egg body and operculum have an exochorion formed by irregular juxtaposed polygonal cells; these cells are without sculpture and the majority of them are hexagonal in shape. The five instars of T. dimidiata can be distinguished from each other by characteristics of the pre, meso and metanotum. The number of setiferous tubercles increases progressively among instars. The sulcus stridulatorium of 1st instar nymphs is amorphous, showing median parallel grooves; from the 2nd instar on the sulcus is, progressively, elongate, deep and posteriorly pointed with stretched parallel grooves. All instars have a trichobothrium on the apical 1/3 of segment II of the antenna. The opening of the Brindley's gland is on the mesopleura. Fifth instar nymphs have an apical ctenidium on the ventral surface of the fore tibia. Dorsal glabrous patches are found on the lateral 1/3 of abdomen. Bright oval patches are found on the ventral median line of the abdomen, from segment IV-VI; 1st instar nymphs lack these patches. Abdominal dorsal plates are present from the 1st-5th instars; the 1st instar also contains a rectangular plate in segment IX. From the 2nd instar on, variably-shaped plates are present on segments VII to IX. Morphometric data were also obtained and proved to be useful for distinguishing T. dimidiata instars.

Key words: Chagas disease - vector - morphology - systematics

The importance of the knowledge of the Triatominae eggs was emphasised by Pinto (1924) when he described and differentiated the eggs of Triatoma brasiliensis Neiva, 1911 and other triatomines found in Brazil. Galliard (1935b) demonstrated that there is a characteristic ornamentation on the external surface of chorion that permits the recognition of different species. The structure and ornamentation of the eggs analysed by light microscopy (LM) are useful in the identification of similar species, i.e., Triatoma maculata (Erichson, 1848) and Triatoma pseudoma-culata Corrêa \& Espínola, 1964 (Gonçalves et al. 1985).

The eggs of 35 species of Triatoma were examined using scanning electron microscopy (SEM); this constitutes less than half the species in the genus. In Table I, a summary of papers using SEM to study the morphology and/or morphometry of eggs and an indication to which group they belong to according to the classification of Barata (1998) is presented.

The subfamily Triatominae has 141 species grouped in 15 genera and five tribes (Jurberg et al. 2009, Schofield \& Galvão 2009). Triatoma dimidiata is found in northwest South America (Peru, Ecuador, Colombia, Venezuela, Guiana), in all of the countries of Central

\footnotetext{
+ Corresponding author: fernanda-mello@fepps.rs.gov.br JJ and JG are CNPq fellowship.

Received 2 May 2009

Accepted 29 September 2009
}

America and in Southern Mexico (Zeledón 1981), with great variability in colour and body proportions according to their source (Fig. 1). T. dimidiata is characterised as being between 24.5-35.0 mm long and having extremely diverse coloration varying from piceous to black with connexivum and corium pale yellow to orange yellow, short, inconspicuous hairs, a head that is wrinkled dorsally, a pronotum that is uniformly piceous or black and legs that are uniformly black (Lent \& Wygodzinsky 1979). Bargues et al. (2008), in a interpopulational analysis of $T$. dimidiata and its closest relatives within Triatoma, combined DNA sequence analyses, phylogenetic reconstruction methods and genetic variation approaches to show that $T$. dimidiata represents a complex of species and subspecies.

The identification of the Triatominae species based only on nymph characteristics is difficult. According to Brewer et al. (1983a), the first keys to separate the 5th instar nymphs were published by Usinger (1944) for some species of Triatominae for North America, by Abalos and Wygodzinsky (1951) for the 1st and 5th instars for some Argentine species and by Ryckman (1962) for the 5th instar of Triatoma protacta (Uhler, 1894) complex. Lent and Wygodzinsky (1979) and Galíndez-Girón et al. (1998) offered keys to identifying distinct genera based on 1st and 5th instar nymphs. Twenty two species of Triatoma had their nymphs described and/or some morphological aspects analysed in SEM (Lent \& Wygodzinsky 1979, Gonçalves et al. 1985, Jurberg et al. 1986, 1991, 1998, 2002, Rosa et al. 1989, 1992a, b, 2005, Rosa 1995, Rocha et al. 1996, 2009, Rosa 


\section{TABLE I}

Summary of the articles on morphology of the eggs of Triatoma species in scanning electron microscopy and the group they belong according to the classification of Barata (1998)

\begin{tabular}{|c|c|c|}
\hline Species & Group & Reference \\
\hline T. arthurneivai Lent \& Martins & 1 & Barata (1998) \\
\hline T. baratai Carcavallo \& Jurberg & 1 & Rocha et al. (2009) \\
\hline T. barberi Usinger & 2 & Barata (1998) \\
\hline T. brasiliensis Neiva & 1 & Jurberg et al. (1986), Costa et al. (1997), Barata (1998) \\
\hline T. brasiliensis macromelanosoma Galvão & 1 & Costa et al. (1997) \\
\hline T. breyeri Del Ponte & 3 & Obara et al. (2007b) \\
\hline T. circummaculata (Stål) & 1 & Barata 1998, Rosa et al. (2000) \\
\hline T. costalimai Verano \& Galvão & 3 & Obara et al. (2007b) \\
\hline T. delpontei Romaña \& Abalos & 2 & Barata (1998) \\
\hline T. dimidiata (Latreille) & 3 & the present paper \\
\hline T. guazu Lent \& Wygodzinsky & 1 & Silva et al. (2000) \\
\hline T. infestans Klug & 1 & Barth and Muth (1958), Barata (1998), Hinton (1981), Jurberg et al. (1998) \\
\hline T. juazeirensis Costa \& Felix ${ }^{a}$ & 1 & Costa et al. (1997) \\
\hline T. jurbergi Carcavallo, Galvão \& Lent & 1 & Jurberg et al. (2002) \\
\hline T. lecticularia (Stål) & 2 & Barata (1998) \\
\hline T. lenti Sherlock \& Serafim & 1 & Barata (1998) \\
\hline T. longipennis Usinger ${ }^{c}$ & 3 & Obara et al. (2007a) \\
\hline T. maculata (Erichson) & 1 & Hinton (1981), Gonçalves et al. (1985) \\
\hline T. matogrossensis Leite \& Barbosa & 1 & Obara et al. (2007b) \\
\hline T. melanica Neiva \& Lent ${ }^{a}$ & 1 & Costa et al. (1997) \\
\hline T. nitida Usinger & 3 & Jurberg et al. (1991) \\
\hline T. oliveirai (Neiva, Pinto \& Lent) & 1 & Barata (1998) \\
\hline T. pallidipennis Stål ${ }^{c}$ & 3 & Obara et al. (2007a) \\
\hline T. patagonica Del Ponte & 1 & Visciarelli et al. (2004) \\
\hline T. phyllosoma (Burmeister) ${ }^{c}$ & 3 & Obara et al. (2007a) \\
\hline T. picturata Usinger ${ }^{c}$ & 3 & Obara et al. (2007a) \\
\hline T. platensis Neiva & 2 & Barata (1998) \\
\hline T. protracta (Uhler) & 2 & Barata (1998) \\
\hline T. pseudomaculata Corrêa \& Espínola & 1 & Gonçalves et al. (1985) \\
\hline T. rubrofasciata (De Geer) & 3 & Haridass (1986) \\
\hline T. rubrovaria (Blanchard) & 1 & Barata (1998), Rosa et al. (2000) \\
\hline T. sordida (Stål) & 1 & Barth \& Muth (1958) \\
\hline T. sherloki Papa, Jurberg, Carcavallo, Cerqueira \& Barata & 1 & Obara et al. (2007b) \\
\hline T. tibiamaculata (Pinto) & 3 & Obara et al. (2007b) \\
\hline T. vandae Carcavallo, Jurberg, Rocha, Galvão, Noireau \& Lent & 1 & Silva et al. (2005) \\
\hline T. williami Galvão, Souza \& Lima & 1 & Silva et al. (2005), Obara et al. (2007b) \\
\hline
\end{tabular}

$a$ : cited as populations of T. brasiliensis pertaining to the varieties juazeiro and melanica; $b$ : cited as T. melanosoma; $c$ : cited as belonging to Meccus; 1: egg ellipsoid, symmetric, collar present, chorial rim in a very narrow rim, exochorion with hexagonal cells with sparse perforations; 2: egg ellipsoid, without collar, chorial rim in a large rim, exochorium not well defined, hexagonal cells absent; 3: intermediate characteristics of groups 1 and 2 .

\& Barata 1997, Galíndez-Girón et al. 1998, Silva et al. 1999a, b, 2000, 2002, 2003, 2005, Naegele et al. 2003). In this paper, the morphological description of eggs and nymphs of $T$. dimidiata using both LM and SEM microscopy is shown to contribute to Triatominae systematic and phylogenetic studies.

\section{MATERIALS AND METHODS}

The specimens used in this study came from intradomicilary populations from Mexico (Vera Cruz, city of Tuxpan), which are the source of the colonies maintained by the laboratories at the Fundação Oswaldo Cruz-Fiocruz. According to Lent and Wygod- 
zinsky (1979) and Bargues et al. (2008), they belong to T. dimidiata maculipennis (Stål, 1859) (Fig. 1). 1st and 2nd instars nymphs were obtained from Laboratório de Triatomíneos e Epidemiologia da Doença de Chagas, Instituto de Pesquisa René Rachou, Belo Horizonte, Minas Gerais, where this species has been maintained since 2002; the nymphs of 3rd, 4th and 5th instars came from Laboratório Nacional e Internacional de Referência em Taxonomia de Triatomíneos, Instituto Oswaldo Cruz-Fiocruz, Rio de Janeiro, where the nymphs have been maintained since 2004 from specimens provided by the first laboratory mentioned above. Illustrations of the five instars were prepared using a camera lucida connected to a stereomicroscope. A measuring eyepiece was used for measurements of the morphometric parameters; the measurements are in millimetres. For SEM analysis, the eggs and nymphs were cleaned in distilled water with an ultrasonic cleaner and, after drying, the samples were mounted in stubs and metallised with gold. Thirty eggs were measured. The morphometric parameters used for the eggs were total length, maximum width and diameter of the operculum. We followed Lent and Wygodzinsky (1979) in the morphometric parameters of the nymphs, which are illustrated in Fig. 2, except for abdomen width and total length.

\section{RESULTS}

\section{Eggs}

(Figs 3-8, Table I)

Egg symmetric and ellipsoid with brilliant white coloration (Fig. 5). The relationship between the diameter of the operculum and the maximum width of the egg was 0.56 ; between the length and width 1.68. Mean total length was $2.15 \pm 0.05$. Maximum width of the egg was $1.28 \pm 0.02$. The diameter of the operculum was $0.72 \pm$ 0.01 . The greatest diameter of each cell was about $25 \mu \mathrm{m}$

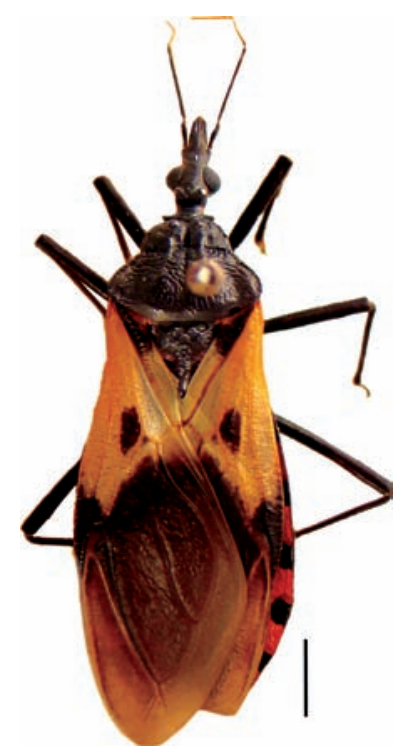

Fig. 1: Triatoma dimidiata. Male, dorsal view. Bar $=5 \mathrm{~mm}$.

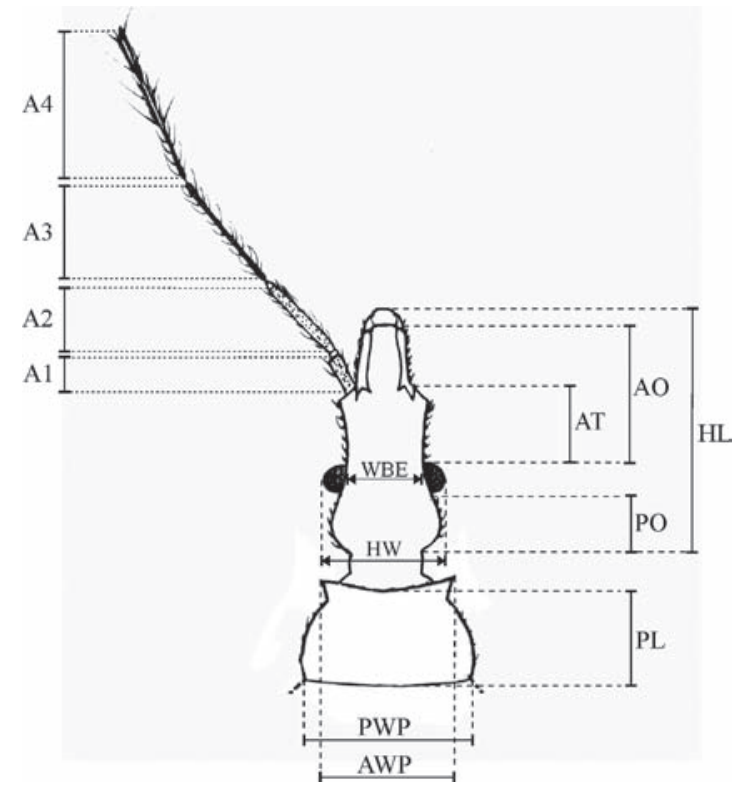

Fig. 2: Triatoma dimidiata. Nymph 2nd instar, dorsal view, head and pronotum, indicating 13 morphometric parameters. AO: length of anteocular portion of head; AT: antenniferous tubercle length; AWP: anterior width of pronotum; A1: length of antennal segment I; A2: length of antennal segment II; A3: length of antennal segment III; A4: length of antennal segment IV; HL: head length; HW: head width; PL: pronotum length; PO: length of postocular portion of head; PWP: posterior width of pronotum; WBE: width between eyes.

(SEM). Operculum circular, slightly convex, the cells tended to be rounded and apparently not contiguous (Figs 3, 4). Exochorium and operculum with contiguous irregular polygonal cells; the majority being hexagonal, with some pentagonal and, rarely, quadrangular; cells without ornamentation (Figs 4, 6, 8). Chorial and opercular borders in narrow ringed shaped bands without cells (Figs 3, 6, 7); cells of the egg body were lightly padded (Fig. 8). With SEM were observed up to the chorial rim, aeropiles, slightly defined spermatic grooves and micropyles on the external surface (Fig. 7).

\section{Nymphs \\ (Figs 9-17)}

First instar (Figs 9, 14, 15; Tables II, III) - Head, thorax and the two last abdominal segments with medium-brown color, abdomen reddish-brown, legs lightbrown. Head, thorax and margins of abdomen covered with conspicuous setiferous tubercles, erect bristles longer than length of tubercle more frequently on the head. Head subcylindrical with bristles inserted in setiferous tubercles concolourous with tegument. Head with its entire surface granular from the clypeus to the neck, with $1+1$ glabrous longitudinal bands, subparallel, delimiting the central area; clypeus subrectangular surpassing gena. Post-ocular cephalic sutures converging, forming a "Y" and continuing to abdominal segment III in some specimens, to abdominal segment I or II; post-ocular region slightly arched. Anteclypeus almost reaching the middle of antennal segment II. Juga apically narrowed. 

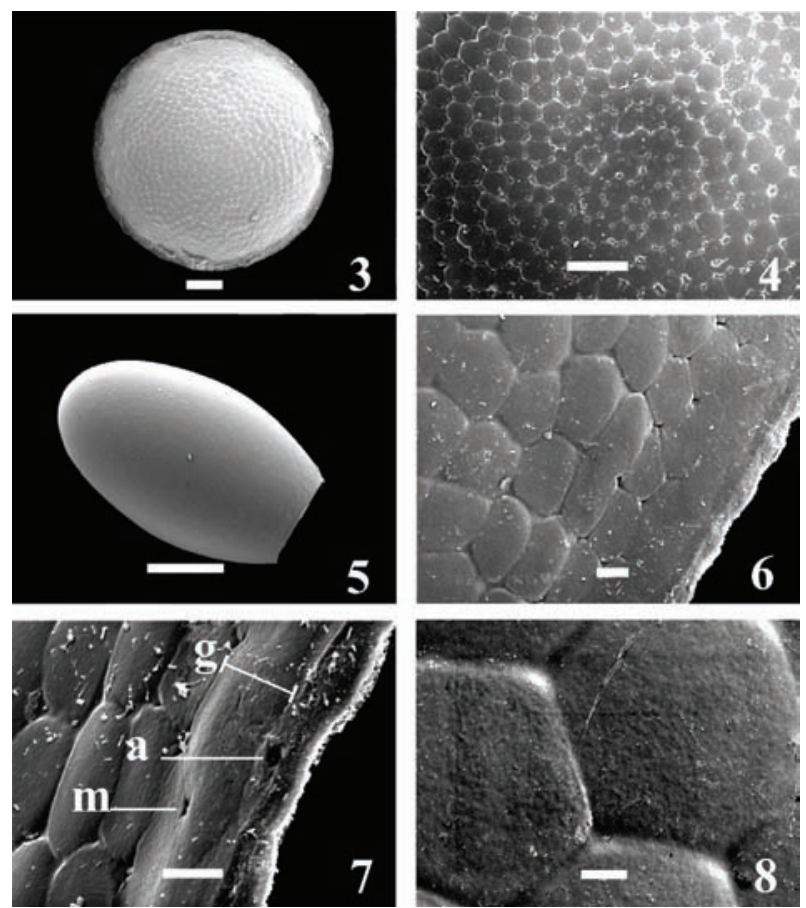

Figs 3-8: Triatoma dimidiata. Egg. 3: operculum (bar $=100 \mu \mathrm{m}) ; 4$ : detail of operculum surface (bar $=50 \mu \mathrm{m})$; 5 : general aspect of egg (bar $=500 \mu \mathrm{m})$; 6 : aspect of chorial $\mathrm{rim}($ bar $=10 \mu \mathrm{m})$; 7 : detail of chorial rim (a: aeropyle; g: spermatic groove; m: micropyle) (bar $=10$ $\mu \mathrm{m})$; 8: detail of exochorial surface (bar $=5 \mu \mathrm{m})$.
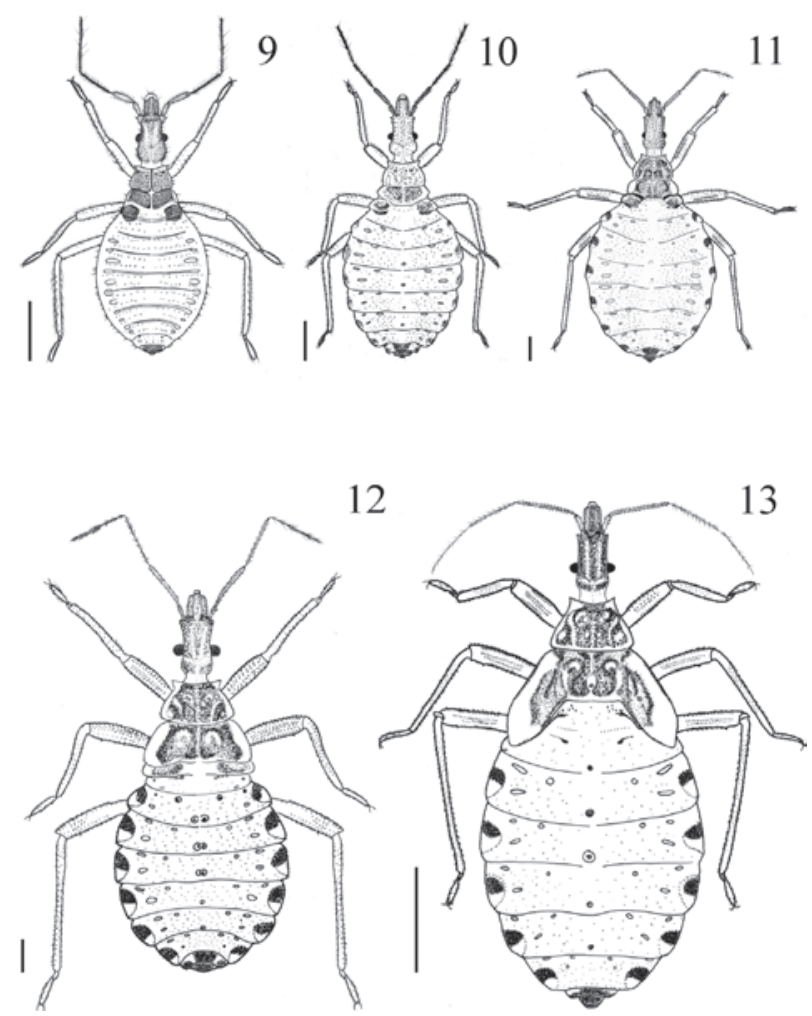

Figs 9-13: Triatoma dimidiata. Nymphs, dorsal view. 9: 1st instar; 10: 2nd instar; 11: 3rd instar; 12: 4th instar (bar $=1 \mathrm{~mm})$ 13: 5th instar (bar $=5 \mathrm{~mm}$ ).
Clypeus and gena covered with bristles, two $(1+1)$ erect on clypeus, two $(1+1)$ curved close the base of the gena and two $(1+1)$ erect on each side of the anteclypeus. Antennae four segmented laterally inserted in tubercles at the edge of anterior third of head; antenniferous tubercles with a pair of apicolateral processes with erect bristles (Fig. 14). Antennae with segments I and II lightbrown, III and basal third of IV medium-brown, apical $2 / 3$ of IV was whitish. The apex of all segments and intersegmental articulations were also pale. Segment I of antenna not reaching the anterior border of clypeus, with slight pilosity; segment II and III with curved bristles, distributed in parallel rows, on basal half of IV with short bristles and on apical half long and short. Segment II with dorsal trichobothrium and reticulated integument on apical third. Segment III with reticulated integument in a basal straight line. The apical half of segment IV had transversally, finely-striped integument. Segments I and II thicker than segments III and IV. The eyes had globose ommatidia (mulberry-like), with a glabrous ventral postero-inferior area without ommatidia. Ventral region of the head medium-brown with granulosity and a few setaceous tubercles on the lateral margins. The gula were light and glabrous from the anterior-ocular region to the neck; this clear area extends to the intraocular region with $1+1$ clear, glabrous oval areas. Rostrum triarticulated, rectilinearly touching base of prosternum, light-brown. Segments I and II with short and sparse pilosity; apical third of segment III with a few long bristles and apically with short bristles. Segment II starting at the level of antenniferous tubercles, ending with apex almost reaching the neck; membrane of articulation quadrangular, slightly swollen, dorsally visible between segments II and III (Fig. 15). Thorax medium-brown. Pronotum subtrapezoidal almost as long as meso and metanotum together, with small setaceous tubercles and $1+1$ discal tubercles; collar with anterolateral angles directed laterally with two $(1+1)$ bristles. A stridulatory furrow was visible in SEM, with irregular stripes and flanked by lateral papillae. Mesonotum medium-brown, formed by $1+$ 1 subrectangular plates, divided by a membranous transverse stripe circled by areas of lighter colour. Mesonotum length almost equal to half of pronotum longer at the middle than in the lateral margins. Metanotum formed by $1+1$ sclerotised rounded sublateral plates, with subrectangular borders wider than half of the distance between them; a few median setaceous tubercles. Legs uniformly light-brown, femur and tibia with decumbent bristles bent linearly in parallel rows; tarsi two-segmented with abundant fine bristles, some erect. Coxae with scarce setaceous tubercles. Submedian ventral surface of the femur with a glabrous area, with $(1+1)$ subapically prominent tubercles. Ventral region of the thorax light-brown; granulose integument medium-brown around the middle and hind coxae; a row of small setaceous tubercles were present between the meso and metasternum. Pleurae was medium-brown with granular integument posterior region with sparse setaceous tubercles more abundant on mesosternum. Brindley's gland oblong opening placed in the mesopleura. The abdomen was void of connexival markings. Urotergite I with $1+1$ anterolateral spiracles. 
Urotergites I-VIII with two transverse lines of setaceous tubercles arranged linearly. There were glabrous dorsal areas on the lateral third of the abdomen and on segments II-VII, with $1+1$ on II and $2+2$ for III-VII; segment VIII with $1+1$ spots adjoining the anterior margin; segment IX almost completely and X totally medium-brown. Bristles on the edges 3-4 times larger than tubercles. Spiracles between the glabrous lateral areas of ventral segments II-VIII. A rectangular sclerotized plate (chitinous plate) on ventral segment IX. The posterior margins of urosternites VII and VIII with $1+1$ long erect bristles directed toward the mid-abdomen.

Second instar (Figs 10, 16; Tables II, III) - Head, thorax and abdominal segments VIII-X with variable coloration in tones of brown; the rest of the abdomen was lighter colored legs lighter than the abdomen. The head, thorax, legs and margins of the abdomen covered with tubercles with decumbent hairs more frequently on the head. The integument of the head was granulose covered with short, implanted bristles in tubercles. The margins of the thorax and abdomen were light-colored. The anteclypeus reaching basal third of II antennal segment. The apex of the juga exceeding the antenniferous tubercle. Neck without tubercles with a medium clear line. Antennal segment I slightly exceeding middle of clypeus. The rostrum light-brown, lighter than the head. Segment II of the rostrum beginning at the apex of antenniferous tubercles, ending almost at the neck. Pronotum with 1 +1 discal tubercles and sparse setaceous tubercles; the glabrous delineated area between tubercles. Mesonotum with $1+1$ kidney-shaped hairless area occupying $3 / 4$ of the length of the pronotum. The metanotum was formed by $1+1$ elliptical plates smaller than the distance between them, with an anterior glabrous area, posterior medium margin with a row of rare setaceous tubercles. The thorax was lighter than abdomen ventrally; setaceous tubercles on meso and metasternum. Prosternum with a stridulatory furrow visible with LM. The abdomen with connexival markings on the lateral edges of each segment; urotergites II-VII with apical 2/3 dark and 1/3 light colour. Segments II-VI with a series of five granule aggregations along the mid line. Urotergite I had $1+1$ linear medium-brown plates at the antero-lateral region, II-VII contained inserted bristles. Segments IIVII contained $3+3$ glabrous dorsal areas at the lateral thirds of the segments. Segment VIII had $2+2$ antero and postero-lateral markings and a central sclerotised and tuberculate plate. Segment IX had lateral markings. Curved hairs on the edges pointed backwards. Segments IV-VI had a median shiny oval area. Sclerotised median plates on urosternites VII-IX bell-like; on VII, occupying posterior 2/3 of urosternite; less large than the median third; was oblong on VIII, was wider than the median third of the urosternite; and occupying the basal area of the urosternite on IX.

Third instar (Figs 11, 17; Tables II, III) - The head, thorax and abdominal segments VIII-X with variable coloration in the tones of brown, legs lighter in colour and the abdomen was reddish. Margins of the thorax light brown. Antennal segment I surpassing middle of the clypeus. The pronotum was trapezoidal less longer than the meso and metanotum together; covered with sparse setaceous tubercles among glabrous areas as follows: $1+1$ hooklike, longitudinal; $2+2$ oval, posterior, at each side of a
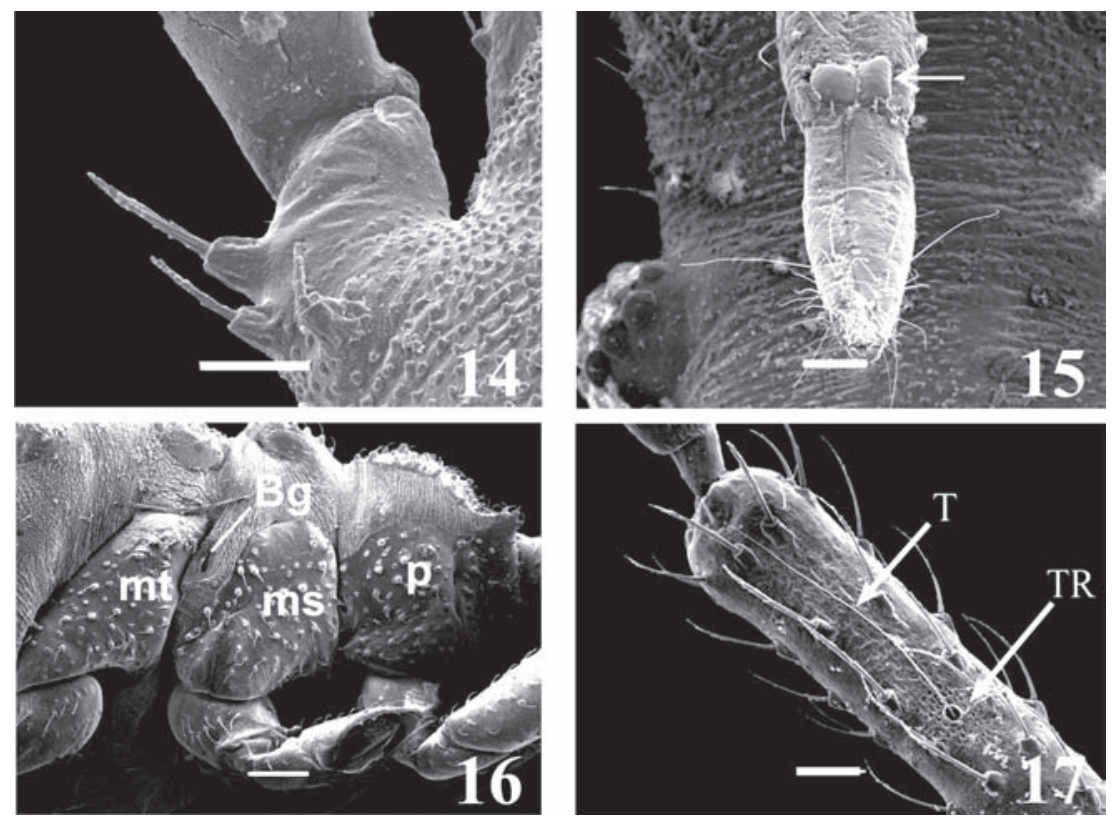

Figs 14-17: Triatoma dimidiata. 14: 1st instar, antenniferous tubercle with apicolateral processes, dorsal view $(\mathrm{bar}=50 \mu \mathrm{m})$; $15: 1 \mathrm{st}$ instar, rostrum, detail of membranous articulation between segments II and III, dorsal view (bar $=50 \mu \mathrm{m}$ ); 16: 2nd instar, thoracic pleuron, lateral view $($ bar $=200 \mu \mathrm{m})(B g$ : Brindley's gland opening; p: propleuron; ms: mesopleuron; mt: metapleuron); 17: 3rd instar, antennal segment II, dorsal view (T: trichobothrium; TR: reticulated integument) $(\mathrm{bar}=50 \mu \mathrm{m})$. 


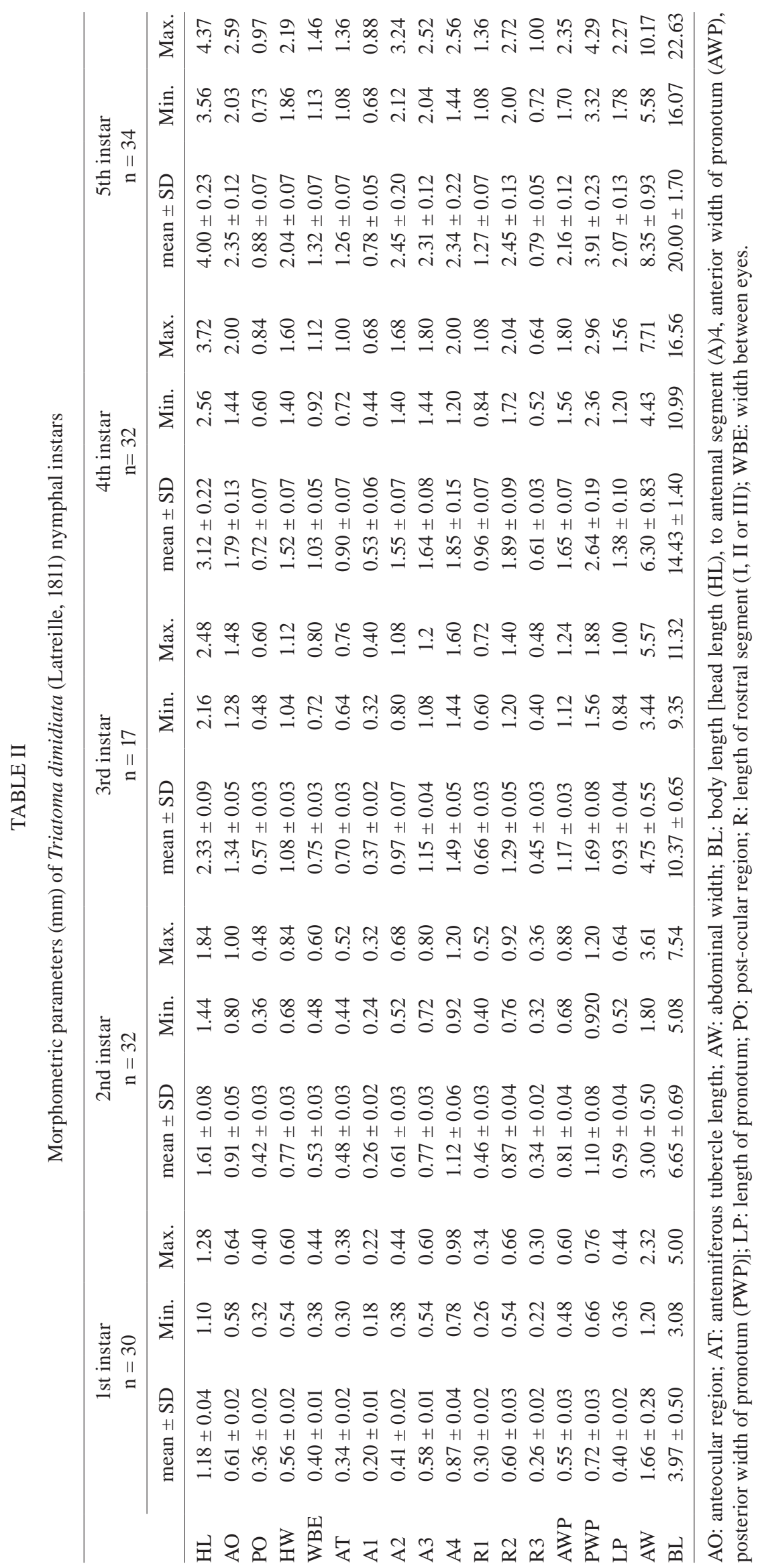




\section{TABLE III}

Proportions means of some characters of instars of Triatoma dimidiata (Latreille, 1811)

\begin{tabular}{lcccccc}
\hline & AO/PO & WH/WBE & Antenna & Rostrum & HL/LP & HL/WH \\
\hline 1st instar & $1: 0.59$ & $1: 0.71$ & $1: 2.08 ; 2.94: 4.43$ & $1: 2.03 ; 0.87$ & $1: 0.34$ & $1: 0.48$ \\
2nd instar & $1: 0.46$ & $1: 0.69$ & $1: 2.37 ; 2.99: 4.31$ & $1: 1.88 ; 0.73$ & $1: 0.37$ & $1: 0.48$ \\
3rd instar & $1: 0.42$ & $1: 0.70$ & $1: 2.61 ; 3.08: 4.01$ & $1: 1.94 ; 0.67$ & $1: 0.40$ & $1: 0.47$ \\
4th instar & $1: 0.40$ & $1: 0.68$ & $1: 2.91 ; 3.06: 3.47$ & $1: 1.97 ; 0.64$ & $1: 0.44$ & $1: 0.49$ \\
5th instar & $1: 0.37$ & $1: 0.65$ & $1: 3.57 ; 2.99: 3.02$ & $1: 1.92 ; 0.62$ & $1: 0.52$ & $1: 0.51$ \\
\hline
\end{tabular}

antenna: ratio of antennal segments, with first segment forming the basic unit of 1; AO/PO: ratio of length of head measured longitudinally from clypeus to anterior border of eye, the clypeus not included and from posterior border of eye to neck; HL/LP: ratio of length of head measured longitudinally from apex of clypeus to neck, the latter not included and pronotum measured midline, from anterior border of collar to posterior margin of hind lobe; HL/WH: ratio of length of head measured longitudinally from apex of clypeus to neck, the latter not included and head measured transversally across eyes; Rostrum: ratio of rostral segments, their relative length, with first segment forming the basic unit of 1; WH/WBE: ratio of head measured transversally across eyes and width between eyes.

sinuous line, one close to the median line and another at the humeral angle; $1+1$ circular, postero-lateral in relation to discal tubercles and $1+1$ kidney-like involving discal tubercles. Mesonotum 1/6 smaller than the length of the pronotum, medium-brown and had $1+1$ kidneylike glabrous areas. The metanotum formed by $1+1$ elliptical plates slightly smaller than the distance between them. Ventral region of the thorax light-brown; setaceous tubercles abundant on the prosternum, sparse on the meso and metasternum. Abdominal segments II-VII had glabrous areas $(3+3)$ on the lateral third. Segment VIII had a central sclerotised plate and many tubercles; segments IX and X were completely medium-brown. Medial margin of spiracles with spicules. Bright oval area, gradually increasing in size from segments IV-VI. Other characteristics were as described for previous instars.

Fourth instar (Fig. 12; Tables II, III) - Head and abdominal segments VIII-X in intense brown tones, abdomen lighter in colour; legs darker than abdomen. Apex of the juga reaching basal third of antennal segment I. Anterior region of the neck with small and scarce tubercles. Segment II of the rostrum beginning at the apex of the antenniferous tubercles ending at the base of the neck. Pronotum trapezoidal equal in length to $3 / 4$ of the meso and metanotum together. Mesonotum less longer than the pronotum. Metanotum formed by $1+1$ elliptical plates that were slightly larger than the distance between them. Wing pads present, first pair reaching the anterior border of the metathorax and the second reaching urotergite I. Ventral thorax with abundant setaceous tubercles on the prosternum, lateral on meso and metasternum. Other characteristics were as described for previous instars.

Fifth instar (Fig. 13; Tables II, III) - Body brown, tibiae and tarsi lighter in colour. The apex of the juga reaching basal portion of antennal segment I. Antennal segment I reaching 2/3 of the clypeus base. The ventral of head with sparse granules near the eyes. The rostrum was the same colour as the head. Segment II of the rostrum beginning at the apex of the antenniferous tubercles at the apical portion of the neck. The pronotum trapezoidal as long as 3/5 of the meso and metanotum together. Mesonotum in more intense brown at the middle and mid margins of wing pads, with $1+1$ kidney-like glabrous areas; the lateral margins of the wing pads were light brown; a granulated protuberance bordered with tubercles at the disc. Metanotum scarcely visible. Wing pads well developped first pair covering second both reaching urotergite II. Integument of pleura darkened and tuberculated. Ventral region of the thorax dark-brown. Prosternum and lateral areas of the meso and metasternum with abundant setaceous tubercles. Meso and metasternum at middle with sparse bristles. The tibiae of the forelegs had ctenidia at the apex of the ventral surface. Segments IIVII with glabrous dorsal areas $(3+3)$ at the lateral third of abdomen; the anterior region of urotergite II with $1+1$ medium-brown straight markings and $2+2$ circular glabrous areas covered by the wing pads. Segments VIII-IX sclerotised and tuberculated. Spiracles on urosternites II-VIII slightly elevated and very close to connexivum between the lateral glabrous areas. Other characteristics were as described for the previous instars.

\section{DISCUSSION}

Eggs - Known data on the morphology of eggs of T. dimidiata refer to observations made by LM. Barata (1981), Costa et al. (1991) and Jurberg et al. (1993) described generic characteristics, using the morphology of eggs for the genera Rhodnius, Cavernicola and Dipetalogaster, respectively. A great variability is present on the genera Alberprosenia, Cavernicola, Dipetalogaster, Eratyrus, Microtriatoma and Psammolestes, which facilitates the identification of each taxon. In Triatoma, at least three patterns could be observed (Barata 1998) (Table I). Exochorion cells void of ornamentation and similar to $T$. dimidiata were found in Triatoma breyere Del Ponte, 1929, Triatoma costalimai Verano \& Galvão, 1958, Triatoma tibiamaculata (Pinto, 1926) and Panstrongylus. Also the eggs of T. dimidiata have form, size and structure (without the ornamentations) very 
similar to Triatoma pallidipennis Stål, 1872, Triatoma picturata Usinger, 1939, Triatoma phyllosoma (Burmeister, 1835) and Triatoma longipennis Usinger, 1939 smooth exochorial structure and slightly separated superficially padded hexagonal cells (Obara et al. 2007a).

Regarding the morphometric data, our median values for the eggs of $T$. dimidiata are similar to the values found by Galliard (1935a) and Lizaraso (1957), if not a little higher; and do not agree with Usinger (1944), who considered the eggs of $T$. dimidiata to be less than $2 \mathrm{~mm}$. Variations can occur and result from both natural and artificial causes, such as colony maintenance and nutrition (Barata et al. 1980). Lizaraso (1957) concluded that populations of the same species, when provided with different laboratory and natural environments, could produce variations that affected the dimensions of the eggs without affecting the characteristics of the chorion, which remained constant. Morphometric studies of 33 Triatoma species were published (Galliard 1935b, Lizaraso 1957, Gonçalves et al. 1985, Haridass 1986, Jurberg et al. 1986, 1998, 2002, 2008, Jurberg \& Vogel 1994, Jurberg \& Campos 1995, Rosa 1995, Rocha et al. 1996, 2009, Costa et al. 1997, Silva et al. 2000, 2005, Visciarelli et al. 2004, Obara et al. 2007a). According to Barata (1998), Triatoma possesses the following means: length, $2.05 \pm 0.08$ and diameter, $1.14 \pm 0.05$. For the species belonging to the group Rubrofasciata, Phyllosoma complex, Dimidiata subcomplex (Schofield \& Galvão 2009), only T. dimidiata has the morphology and morphometrics of the eggs known. Of the eggs previously studied, the eggs of T. dimidiata are smaller in length and width than the eggs of T. picturata (2.37/1.478), $T$. phyllosoma (2.364/1.468), T. longipennis (2.202/1.368) and T. pallidipennis (2.200/1.418).

Nymphs - Forty three species of Triatoma had their nymphs described and/or some morphological aspect presented by LM and/or SEM (Espínola 1966, Galvão \& Fuentes 1971, Perlowagora-Szumlewicz \& Cruz 1972, Lent \& Wygodzinsky 1979, Brewer et al. 1981, 1983a, b, Jiménez \& Fuentes 1981, Gonçalves et al. 1985, Haridass 1986, Jurberg et al. 1986, 1991, 1998, 2002, 2009, Brewer \& Garay 1989, Rosa et al. 1989, 1992a, b, 2005, Jurberg \& Vogel 1994, Jurberg \& Campos 1995, Rosa 1995, Rocha et al. 1996, 2009, Rosa \& Barata 1997, Galíndez-Girón et al. 1998, Silva et al. 1999a, b, 2000, 2002, 2003, 2005, Naegele et al. 2003). A total of 32 species were shown through illustrations, 31 with photos in LM and 24 using SEM.

Morphology - The five instars of $T$. dimidiata can be distinguished one from the other principally by the dorsal aspect of the thoracic segments (Figs 9-13). The number of setaceous tubercles increases progressively with the development of the nymphs. On the 1st instar, the bristles are erect; the bristles are curved on the 2nd-5th instars. The surface of the body is covered with short bristles imbedded in tubercles, which become more frequent with the development. On the 1st instar, the eyes have globose ommatidia separated so as to appear like the fruit of the mulberry; the later instars increase the number of ommatidia and decrease the space between them.
All of the instars of $T$. dimidiata have trichobothria dorsally on apical third of antennal segment II (Fig. 15).

Lent and Wygodzinsky (1979) highlighted the taxonomic importance of the stridulatory furrow in the characterisation of the species that vary in form, size, number of grooves and the space between them. In T. dimidiata the stridulatory furrow varied among instars. It is amorphous with central parallel stripes and a group of papillae on both sides in the 1st instar. The stridulatory furrow becomes progressively longer, deeper and tapered posteriorly, with parallel stripes becoming closer and lateral tubercles becoming more numerous in the later instars.

Lent and Wygodzinsky (1979) did not examine the 1st instar nymphs metatarsi being unable to define the position of $T$. dimidiata into groups and complexes. They considered $T$. dimidiata “....superficially somewhat similar to the species of the phyllosoma group...”. In the present work, we observed that the 1st instar nymphs presented delicate hairs on the metatarsi of the posterior legs.

The forelegs of 5 th instar nymphs of $T$. dimidiata have ctenidia on the apex of the ventral surface of the tibia. Gonçalves et al. (1985), Costa et al. (1991), Rosa (1995) and Naegele et al. (2003) mentioned the presence of ctenidia on the forelegs of Triatominae nymphs. The ventral surface of the femur of $T$. dimidiata has $1+1$ prominent subapical tubercles with bristles smaller than the tubercles. Tubercles on the submedian surface of the femur were described by Rosa (1995), Galíndez-Girón et al. (1998), Jurberg et al. (2002) and Naegele et al. (2003). Jurberg et al. (2002) described for nymphs of T. jurbergi Carcavallo, Galvão \& Lent, 1998, $1+1$ tubercles in the dorsal subapical surface of the femur of metathoracic legs and $2+2$ in the ventral subapical surface of the meso and metathoracic legs. Naegele et al. (2003) mentioned the presence of $2+2$ tubercles in the ventral apical surface of the femur of pro and mesothoracic legs of Triatoma infestans.

All instars of T. dimidiata have an oblong evaporative opening of the Brindley's gland on the mesopleura (Fig. 16). Schofield and Upton (1978) described these glands in adults of Panstrongylus megistus (Burmeister, 1835), commenting that nymphs are void of them. Millen et al. (1979) apud Rosa et al. (2005) described the development of the Brindley's glands in 5th instar nymphs of Rhodnius prolixus; Rosa (1995) observed these glands in 1st and 5th instar nymphs of Triatoma circummaculata (Stål, 1859) and Triatoma rubrovaria and Rosa et al. (2005) recorded the Brindley's glands in the mesopleura of 5th instar nymphs of Triatoma arthurneivai Lent \& Martins, 1940.

Lent and Wygodzinsky (1979) described the urotergites of the 5th instar nymphs of $T$. dimidiata with a series of five aggregations of granules along the midline and a finely granulose integument. We observed these aggregations of granules along the longitudinal median line of segments II-VI (Figs 10-13).

The glabrous dorsal and ventral areas of the abdomen of Triatominae nymphs were described as elliptical regions by Del Ponte (1920). These areas are bright and round and are placed on median third of each segment. In nymphs of $T$. dimidiata the glabrous dorsal areas on the lateral third of the abdomen are arranged as follows: 1 st instar on segments II-VII, with $1+1$ on II and $2+2$ 
for III-VII (Fig. 9); in later instars, 3 + 3 for II-VII (Figs 10-13). The glabrous areas were mentioned by Gonçalves et al. (1985), Jurberg et al. (1986, 1991, 1998), Rosa (1995) and Rosa and Barata (1997). The bright areas placed in the ventral abdominal region of Triatominae were also described by Del Ponte (1920). In 1997, Rosa and Barata described the abdominal segments of 5th instar nymphs of six species of Triatominae (P. megistus, Rhodnius neglectus Lent, 1954, T. brasiliensis, T. infestans, Triatoma matogrossensis Leite \& Barbosa, 1953 and T. tibiamaculata); the presence of bright round areas in the middle of segments IV-VI were registered, with the exception of $R$. neglectus. The bright areas in T. dimidiata are oval and coincide with the placement observed by Rosa and Barata (1997). As in T. dimidiata, the 1st instar nymphs of T. circummaculata and T. rubrovaria do not have these bright areas (Rosa 1995).

The chitinous plates were described for 5th instar nymphs of $T$. dimidiata; these structures were named by Galliard (1935a). Rosa and Barata (1997) described the chitinous plate as a black, brilliant, hairy area with an oblong form placed on urosternite VII for the triatomines studied, with the exception of $R$. neglectus. In $T$. dimidiata, the chitinous plates are found in all instars.

Morphometrics - Brewer et al. (1983b) studied T. infestans, Triatoma platensis Neiva, 1913, Triatoma delpontei Romaña y Abalos, 1947, and Triatoma sordida (Stål, 1859) and quantitatively analysed which characteristics were the most effective for distinction of the instars of a species and distinction of each one of the instars among different species. Comparing instars of one species, the parameters for which the means differed the most were head length, body length and segment III of the rostrum. These measurements, with the development of nymphs, became extremely useful to distinguish them. Analysing the means of the variables observed in $T$. dimidiata, it was concluded that there is a progressive increase from one to another instar. Considering the range of the following measurements, length of pronotum, posterior width of pronotum, length of segment III of the rostrum and length of antennal segments II and III, they do not overlap along instar development; the posterior width of pronotum was the parameter with the greatest range. On the other hand, the other two parameters suggested by Brewer et al. 1983b, length of the head and total length, did overlap in nymphs of the 4th and 5th instars and the 3rd, 4th and 5th instars, respectively (Table II).

A quantitative analysis of $T$. dimidiata measurements corroborates conclusions made by Brewer et al. (1983b): (i) the anterior ocular region progressively increases in relation to the post-ocular region, (ii) the length of antennal segments I-III is always greater than the length of segment IV, (iii) the length of antennal segment IV progressively increases with development and (iv) the relation between the proportions of the segments I and II of the rostrum and head length/width between eyes are constant through all of the instars.

The means of the variables are progressively higher from the 1st-5th instar. However, when the range of the variables is compared, they overlap. Then, by the analy- sis of the means, it is not possible to distinguish one instar from the other.

The proportions of the means are presented in Table III.

\section{ACKNOWLEDGEMENTS}

To Dra. Paz María Salazar Schettino, from Departamento de Microbiologia y Parasitologia de la Facultad de Medicina - UNAM, for providing informations about the origin of Triatoma dimidiata in Mexico, and to Vanda Cunha and José Eloy dos Santos Júnior, from FIOCRUZ, for sending the specimens studied in this paper.

\section{REFERENCES}

Abalos JW, Wygodzinsky P 1951. Las Triatominae Argentinas (Reduviidae: Hemiptera), Monografia 2, Publicación 601, Universidade Nacional de Tucúman, Instituto de Medicina Regional, Tucumán, 179 pp.

Barata JMS 1981. Aspectos morfológicos de ovos de Triatominae. II - Características macroscópicas e exocoriais de dez espécies do gênero Rhodnius Stål 1859 (Hemíptera: Reduviidae). Rev Saude Publica 15: 490-542.

Barata JMS 1998. Estruturas macroscópicas e exocoriais de ovos de Triatominae (Hemíptera: Reduviidae). In RU Carcavallo, I Galíndez Girón, J Jurberg, H Lent, Atlas of Chagas' disease vectors in Americas, Vol. II, Fiocruz, Rio de Janeiro, p. 409-448.

Barata JMS, Santos JLF, Leite CAP 1980. Aspectos morfológicos de ovos de Triatominae. I - Mensuração de dez espécies do gênero Rhodnius Stål 1856 (sic) (Hemíptera: Reduviidae). Rev Bras Entomol 24: 197-214.

Bargues MD, Klisiowicz DR, Gonzalez-Candelas F, Ramsey JM, Monroy C, Carlos Ponce C, Salazar-Schettino PM, Panzera F, Abad-Franch F, Sousa OE, Schofield CJ, Dujardin JP, Guhl F, Mas-Coma S 2008. Phylogeography and genetic variation of Triatoma dimidiata, the main Chagas disease vector in Central America and its position within the genus Triatoma. PloS 2: 1-19.

Barth R, Muth H 1958. Estudos anatômicos e histológicos sôbre a subfamília Triatominae (Heteroptera: Reduviidae). VIII parte: observações sobre a superfície dos ovos das espécies mais importantes. Mem Inst Oswaldo Cruz 56: 197-208.

Brewer M, Garay M 1989. Identificatión de los estadios ninfales de las espécies del genero Triatoma Laporte 1833 (Hemíptera: Reduviidae). IV. Especies peridomiciliadas em la provincia de Cordoba, Argentina. Rev Soc Entomol Argent 45: 279-297.

Brewer M, Garay M, Gorla D, Murua F, Favot R 1981. Caracterizacion de los estadios ninfales del genero Triatoma Laporte 1833. I. Triatoma infestans Klug, 1834 (Hemiptera: Reduviidae). Rev Soc Entomol Argent 40: 91-102.

Brewer M, Garay M, Gorla D, Murua F, Favot R 1983a. Caracterizacion de los estadios ninfales del genero Triatoma Laporte 1833. II. Triatoma platensis Neiva 1913, Triatoma delpontei Romaña y Abalos 1947, Triatoma sordida (Stål) 1859. (Hemiptera: Reduviidae). Rev Soc Entomol Argent 42: 219-241.

Brewer M, Gorla D, Garay M 1983b. Caracterizacion de los estadios ninfales del genero Triatoma Laporte 1833. III. Analisis biometrico descriptivo de Triatoma infestans Klug, 1834; Triatoma platensis Neiva 1913; Triatoma delpontei Romaña y Abalos 1947, Triatoma sordida (Stål, 1859) (Hemiptera: Reduviidae). Rev Soc Entomol Argent 42: 81-88.

Costa J, Barth OM, Marchon-Silva V, Almeida CE, Freitas-Sibajev MGR, Panzera F 1997. Morphological studies on the Triatoma brasiliensis Neiva, 1911 (Hemiptera: Reduviidae: Triatominae) genital structures and eggs of different chromatic forms. Mem Inst Oswaldo Cruz 92: 493-498. 
Costa JM, Jurberg J, Barth MO 1991. Estudos morfológicos de Cavernicola lenti Barret \& Arias, 1985 (Hemiptera: Reduviidae: Triatominae). Mem Inst Oswaldo Cruz 86: 247-263.

Del Ponte E 1920. Contribución al estudio del gen. Triatoma Lap. Parte 1. Anatomia externa. Rev Inst Bact Dep Nac Hig 2: 729-744.

Espínola H 1966. Nota sobre diferenças sexuais em formas imaturas de Triatominae (Hemíptera: Reduviidae). Rev Brasil Biol 26: 263-267.

Galíndez-Girón I, Rocha DS, Lent H, Carcavallo RU, Jurberg J, Galvão C, Santos HS, Martinez A, Barata JMS, Rosa JA 1998. Nymphal stages. In RU Carcavallo, I Galíndez-Girón, J Jurberg, $\mathrm{H}$ Lent (eds.), Atlas of Chagas' disease vectors in Américas, Vol. II, Editora Fiocruz, Rio de Janeiro, p. 449-513.

Galliard H 1935a. Recherches sur les réduvidés hémathophages Rhodnius et Triatoma. Ann Parasitol Hum Comp 13: 289-306.

Galliard H 1935b. Recherches sur les réduvidés hémathophages Rhodnius et Triatoma. IV Organes génitaux femelles. Ann Parasitol Hum Comp 13: 497-527.

Galvão AB, Fuentes FB 1971. Descrição das ninfas de Triatoma williami (B. Galvão \& col., 1965) e T. deanei (B. Galvão \& col., 1967) (sic). Rev Goiana Med 17: 141-145.

Gonçalves TCM, Jurberg J, Costa JM, Souza W 1985. Estudo morfológico comparativo de ovos e ninfas de Triatoma maculata (Erichsson, 1848) e Triatoma pseudomaculata Corrêa \& Espínola, 1964 (Hemíptera: Reduviidae: Triatominae). Mem Inst Oswaldo Cruz 80: 263-276.

Haridass ET 1986. Ultrastructure of the eggs of Reduviidae: III. Eggs of Triatominae and Echtrichodiinae (Insecta-Heteroptera). Proc Indiana Acad Sci (Anim Sci) 95: 447-456.

Hinton HE 1981. Biology of the eggs, 3 vols, Permagon Press, New York, 1125 pp.

Jiménez OH, Fuentes O 1981. Triatoma flavida (Hemiptera: Reduviidae). I. Estudo biométrico de larvas. Rev Cubana Med Trop 33: $195-200$

Jurberg J, Campos P 1995. Morfologia de huevos y ninfas de Triatoma vitticeps (Stål, 1859) (Hemiptera: Reduviidae). Entomol Vect 2: 9-22.

Jurberg J, Fagundes LM, Barth OM 1993. Estudo morfológico de ovos e ninfas de Dipetalogaster maxima (Uhler, 1894) (Hemiptera: Reduviidae: Triatominae). Rev Brasil Biol 53: 269-283.

Jurberg J, Galvão C, Barth OM 1991. Estudo morfológico de ovos e ninfas de Triatoma nitida Usinger 1939 (Hemíptera: Reduviidae: Triatominae). Rev Bras Biol 51: 365-372.

Jurberg J, Galvão C, Santos CM, Rangel MBA 2008. Descrição de ovos e estádios ninfais de Triatoma carcavalloi (Hemiptera: Reduviidae) por meio de microscopia óptica. Iheringia Ser Zool 98: $441-446$

Jurberg J, Gonçalves TCM, Costa JM, Souza W 1986. Contribuição ao estudo morfológico de ovos e ninfas de Triatoma brasiliensis Neiva, 1911 (Hemíptera: Reduviidae: Triatominae). Mem Inst Oswaldo Cruz 81: 111-120.

Jurberg J, Lima MG, Rocha DS, Carcavallo RU, Galvão C 1998. Descrição de ovos e ninfas de Triatoma melanosoma Martinez, Olmedo \& Carcavallo, 1987 (Hemiptera: Reduviidae). Entomol Vect 5: 67-84.

Jurberg J, Rocha DS, Galvão C 2009. Rhodnius zeledoni sp. nov. afim de Rhodnius paraensis Sherlock, Guitton \& Miles, 1977 (Hemiptera: Reduviidae: Triatominae). Biota Neotrop 9: 123-128.

Jurberg J, Silva MBA, Galvão C, Rocha DS, Barbosa HS, Carcavallo RU 2002. Descrição dos ovos e dos estádios ninfais de Triatoma jurbergi Carcavallo, Galvão \& Lent, 1998 vistos através de microscopia óptica e eletrônica de varredura (Hemiptera: Reduviidae). Mem Inst Oswaldo Cruz 97: 209-216.

Jurberg J, Vogel M 1994. Morfologia de huevos y ninfas de Triatoma matogrossensis Leite \& Barbosa, 1953 (Hemiptera: Reduviidae). Entomol Vect 6: 167-177.

Lent H, Wygodzinsky P 1979. Revision of the Triatominae (Hemiptera: Reduviidae) and their significance as vectors of Chagas' disease. Bull Am Mus Nat Hist 163: 123-520.

Lizaraso Y 1957. Estudio morfológico de los huevos de alguns triatominos hallados em el Perú: Reduviidae: Hemiptera. Rev Peru Med Exp Salud Publica 11: 51-69.

Naegele MP, Barata JMS, Cilense M, Rosa JA 2003. Estudo morfológico e morfométrico de pernas de ninfas de $1^{\circ}$ e $2^{\circ}$ estádios de Mepraia spinolai (Porter, 1934), Panstrongylus megistus (Burmeister, 1835), Rhodnius prolixus (Stål, 1859) e Triatoma infestans (Klug, 1834) (Hemiptera: Reduviidae). Entomol Vect 10: 223-235.

Obara MT, Barata JMS, Silva NN, Ceretti Jr W, Urbinatti PR, Rosa JA, Jurberg J, Galvão C 2007a. Estudo dos ovos de quatro espécies do gênero Meccus (Hemíptera: Reduviidae: Triatominae), vetores da doença de Chagas. Mem Inst Oswaldo Cruz 102: 13-19.

Obara MT, Rosa JA, Silva NN, Ceretti Jr W, Urbinatti PR, Barata JMS, Jurberg J, Galvão C 2007b. Estudo morfológico e histológico dos ovos de seis espécies do gênero Triatoma (Hemíptera: Reduviidae). Neotrop Entomol 36: 798-806.

Perlowagora-Szumlewicz A, Cruz HN 1972. Triatominae (Hemiptera: Reduviidae): sex identification in immatures forms of vectors of Chagas disease. Rev Inst Med Trop Sao Paulo 14: 6-11.

Pinto C 1924. Biologia do Triatoma brasiliensis Neiva. Sci Med 2: 541:543.

Rocha DS, Jurberg J, Galvão C 1996. Descrição dos ovos e ninfas de Triatoma lecticularia (Stål, 1859) (Hemiptera: Reduviidae: Triatominae). Entomol Vect 3: 123-135.

Rocha DS, Jurberg J, Rosa JA da, Schaefer CW, Galvão C 2009. Description of eggs and nymphal instars of Triatoma baratai Carcavallo \& Jurberg, 2000 based on optical and scanning electron microscopy (Hemiptera: Reduviidae: Triatominae). Zootaxa 670: $1-12$.

Rosa JA 1995. Contribuição ao estudo morfológico de ovos e ninfas de $1^{\circ}$ e $5^{\circ}$ estádios de Triatoma circummaculata (Stål, 1859) e Triatoma rubrovaria (Blanchard, 1843) (Hemiptera: Reduvidae), $\mathrm{PhD}$ Thesis, Instituto de Ciências Biomédicas, Universidade de São Paulo, São Paulo, 209 pp.

Rosa JA, Barata JMS 1997. Aspectos morfológicos de abdômen de ninfas de $5^{\circ}$ estádio de seis espécies de Triatominae (Hemiptera: Reduviidae) por microscopia óptica. Rev Cienc Farm 18: 249-270.

Rosa JA, Barata JMS, Barelli N 1989. Cerdas abdominais de espécies de Triatominae através de microscopia eletrônica de varredura. Mem Inst Oswaldo Cruz 84 (Suppl. II): 117.

Rosa JA, Barata JMS, Barelli N 1992a. Spiracles of 5th instar nymphs in six species of Triatominae (Hemiptera: Reduviidae) using scanning electron microscopy. Mem Inst Oswaldo Cruz 87: 301-302.

Rosa JA, Barata JMS, Barelli N, Santos JLF, Belda Neto FM 1992b. Sexual distinction between 5th instar nymphs of six species (Hemiptera: Reduviidae). Mem Inst Oswaldo Cruz 87: 257-264.

Rosa JA, Barata JMS, Santos JLF, Cilense M 2000. Morfologia de ovos de Triatoma circummaculata e Triatoma rubrovaria (Hemiptera: Reduvidae). Rev Saude Publica 34: 538-542. 
Rosa JA, Medeiros MP, Cilense M, Barata JMS 2005. Morphological study of the thorax of the five nymphal instars of Triatoma arthurneivai Lent \& Martins (Hemiptera: Reduviidae: Triatominae). Rev Brasil Entomol 49: 289-293.

Ryckman R 1962. Biosystematics and hosts of the Triatoma protacta complex in North America (Hemiptera: Reduviidae) (Rodentia: Cricetidae). Univ California Publ Entomol 27: 93-240.

Schofield CJ, Galvão C 2009. Classification, evolution and species groups within Triatominae. Acta Tropica 110: 88-100.

Schofield CJ, Upton CP 1978. Brindley's scent-glands and the metasternal scent-glands of Panstrongylus megistus (Hemiptera: Reduviidae: Triatominae). Rev Bras Biol 38: 665-678.

Silva MBA, Barbosa HS, Carcavallo RU, Galvão C, Jurberg J 1999a. Placas apicais do lábio das ninfas de $1^{\circ}$ estádio de Triatoma guazu Lent \& Wygodzinsky, 1979 e Triatoma jurbergi Carcavallo, Galvão \& Lent, 1998 (Hemiptera: Reduviidae) vetores da doença de Chagas. Entomol Vect 6: 663-668.

Silva MBA, Barbosa HS, Galvão C, Jurberg J, Carcavallo RU 2003. Comparative study of stridulatory sulcus, buccula and rostrum of nymphs of Triatoma guazu Lent \& Wygodzinsky, 1979 and Triatoma jurbergi Carcavallo, Galvão \& Lent, 1998 by scanning electron microscopy (Hemiptera: Reduviidae). Mem Inst Oswaldo Cruz 98: 335-344.

Silva MBA, Barbosa HS, Jurberg J, Galvão C, Carcavallo RU 2002. Comparative ultrastructural analysis of antennae of Triatoma guazu and Triatoma jurbergi (Hemiptera: Reduviidae) during the nymphal stage development. J Med Entomol 39: 705-715.

Silva MBA, Jurberg J, Barbosa HS, Rocha D, Carcavallo RU, Galvão C 2005. Morfologia comparada dos ovos e ninfas de Triatoma vandae Carcavallo, Jurberg, Rocha, Galvão, Noireau \& Lent, 2002 e Triatoma williami Galvão, Souza \& Lima, 1965 (Hemiptera: Reduviidae). Mem Inst Oswaldo Cruz 100: 649-661.

Silva MBA, Jurberg J, Galvão C, Carcavallo RU 1999b. Estudo morfológico e morfométrico de ovos e ninfas de Triatoma guazu Lent \& Wygodzinsky, 1979 (Hemiptera: Reduviidae: Triatominae) vistos por microscopia óptica e eletrônica de varredura. Entomol Vect 7: 311-334.

Silva MBA, Jurberg J, Galvão C, Carcavallo RU 2000. Estudos morfológicos de ovos e ninfas de Triatoma guazu Lent \& Wygodzinsky, 1979 (Hemiptera: Reduviidae: Triatominae), vistos por microscopia óptica e eletrônica de varredura. Entomol Vect 7: 331-334.

Usinger RL 1944. The Triatominae of North and Central America and West Indies and their public health significance. Public Health Bull 228: 1-83.

Visciarelli E, Ferrero A, Costamagna SR 2004. Aspectos exocoriales de huevos de Triatoma patagonica Del Ponte, 1929 por microscopía electrónica de barrido. Entomol Vect 11: 653-668.

Zeledón R 1981. El Triatoma dimidiata (Latreille, 1811) y su relación con la enfermedad de Chagas, Ed. Universidad Estatal a Distancia, San Jose, 146 pp. 